\title{
SUNFLOWER SEED QUALITY AND YIELD IN RELATION TO ENVIRONMENTAL CONDITIONS OF PRODUCTION REGION
}

\author{
Mrdja, J. ${ }^{*}$, Crnobarac, J. $^{2}$, Radić, V. ${ }^{1}$, Miklič, V. $^{1}$ \\ ${ }^{1}$ Institute of Field and Vegetable Crops, Oil Crops Department, \\ Maksima Gorkog 30, 21000 Novi Sad, Republic of Serbia \\ ${ }^{2}$ Faculty of Agriculture, University of Novi Sad, Trg Dositeja Obradovića 8, \\ 21000 Novi Sad, Republic of Serbia
}

Received: November 12, 2011

Accepted: December 10, 2012

\begin{abstract}
SUMMARY
Seed quality is a complex character that is determined by a large number of parameters. Because of this, knowing the interrelationships among these parameters is of utmost importance, not only from the point of view of plant selection but also from the standpoint of crop production itself. The objective of this study was to investigate the influence of production season and production region (i.e., environmental conditions) on quality parameters and yield of sunflower hybrid seed. The study was conducted on the seed of the hybrids NS-H-111 and Rimi that had been produced at sites located in Serbia and Ukraine. The following traits were studied: germinability, 1000-seed weight, husk content, protein content, and seed yield per hectare. All of the studied parameters were affected the most by the genotype itself. Germinability ranged from $87.75 \%$ in NS-H-111 produced in Serbia to $95.50 \%$ in Rimi produced in Ukraine. The 1000-seed weight was greatly influenced by the production area. All of the studied factors individually produced highly significant differences in husk content, which ranged from $20.35 \%$ in NS-H- 111 to $31.40 \%$ in Rimi. Seed protein content was highly significantly affected by all the factors studied. On average, genotype had the greatest effect on seed yield as well, with the difference in yield between the hybrids $(833.0 \mathrm{~kg}$ ) being highly significant. On the average, looking at the production season and area, differences were observed with regard to seed yield, but those were not statistically significant.
\end{abstract}

Key words: environmental conditions, seed yield, seed quality, sunflower

\section{INTRODUCTION}

Sunflower is one of the most important oilseed crops on a global level, grown on a total of over 22 million hectares worldwide (Škorić et al., 2008). Due to the

* Corresponding author: Phone: (+381) 214898 429; Fax: (+381) 216413 833; e-mail: jelena.mrdja@nsseme.com 
areas on which it is grown and the large areal extent, this crop requires the production of high quality seed (Vujaković et al., 2012), because crop growers have become increasingly aware of the importance of seeds that are capable of quick and uniform germination in different environmental conditions, as required by the modern methods of agricultural production (Mrdja et al., 2011).

Sunflower seed production has as its primary goal the production of genetically and physically pure seeds that are physiologically mature and healthy and have as much germination energy and germinability as possible as well as tolerance of agroecological stress (Miklič et al., 2011). In order to be able to meet the increased grower demand for sunflower hybrids that are of as high quality and as high-yielding as possible, it is necessary that the current hybrid product range be rapidly replaced with a new set of hybrids that are better, more productive, and more stable. The development of high-yielding hybrids coupled with the use of appropriate agronomic practices reduces the impact of limiting factors in sunflower production and contributes to the increase of sunflower yields (Miklič et al., 2010).

Success in sunflower growing and production depends not only on the genetic potential of the genotype but also on environmental conditions. Productivity and quality are greatly influenced by genotype, environment and their interaction (Sidlauskas and Bernotas, 2003; Denčić et al., 2011). The extent of the genotype $\times$ environment interaction is a product of the variation of uncontrolled factors, which vary on a year to year basis (Adugna and Labuschange, 2002). By virtue of this, therefore, knowing how environmental factors impact plant growth and development would reduce the possibility of sustaining significant yield and seed quality losses. To minimize the effects of these factors, one of the measures is to identify and use stable cultivars (Nasayao and Saladaga, 1988; Marjanović-Jeromela et al., 2011). Unfavorable environmental conditions lead to variations in seed size and quality, to mechanical injury of seeds and damage during seed storage, and to disease attacks (Chloupek et al., 2003; Rahman et al., 2009). In sunflower production it is therefore important to use stable parental lines that will perform well enough in different environments (Moghaddam and Pourdad, 2011).

Changes in environmental conditions during the seed filling period potentially affect sunflower yield components (Aguirrezabal et al., 2003). In order to be able to produce seed materials of high quality, the seed production itself should be stable and economical. Such production can be carried out in areas in which the commercial sunflower crops produce the highest yields. These are areas with fertile soils that have sufficient rainfall amounts and a good distribution of rainfall during the growing season. These production areas should have a temperate climate with no extreme temperatures during the growing season, because the growing season conditions also affect the parameters of seed quality (Radić et al., 2009). Seed quality parameters are a sum of all seed characteristics that result in fast and uniform emergence after planting as well as in the formation of strong and healthy seedlings 
and optimal stand density, all of which affects the uniformity of the crop and the potential for yield (Nyachiro et al., 2002; Hrstkova et al., 2006).

The objective of this study was to investigate how the production season and production region and hence environmental conditions affect the quality parameters and yield of sunflower hybrid seeds.

\section{MATERIALS AND METHODS}

\section{Plant material}

Seeds originating from commercial sunflower production were used as the study materials. The production itself was established in a number of locations and areas, and the present paper discusses the data from two of the production areas spanning a period of two growing seasons.

The trial involved the hybrids NS-H-111 and Rimi, both of which had been developed at the Institute of Field and Vegetable Crops in Novi Sad, Serbia. NS-H111 is a standard oilseed hybrid characterized as medium early. It is one of the most commonly grown hybrids in Serbia and the whole of southeastern Europe. Rimi is a medium early hybrid tolerant of imidazolinone-based herbicides that has been developed by conventional breeding methods.

\section{Trial environmental conditions}

The study was performed on seeds produced in locations in Serbia (the Padinska Skela site) and Ukraine (the Kirovohrad site). These locations were chosen because sunflowers like fertile and deep soils the best, as it is on such soils that the profitability of sunflower growing comes becomes fully apparent. The same growing technology was used with both hybrids throughout - from the actual planting and the alternation of male and female rows to the use of appropriate agronomic practices.

The Kirovhrad area in Ukraine has a temperate continental climate. The winters are mild with frequent rains and melting of snow. Snow cover forms fairly late in early December. The spring comes relatively early. The summers are warm and dry and often there is no precipitation whatsoever. The average annual temperature is $8.0^{\circ} \mathrm{C}$, with the low of $-15.0^{\circ} \mathrm{C}$ coming in January and the high of $35.0^{\circ} \mathrm{C}$ in July. The average January and July temperatures are $-5.5^{\circ} \mathrm{C}$ and $21.0^{\circ} \mathrm{C}$, respectively. The window for the appearance of frost spans 160-170 days annually. Precipitation most often comes in the form of rain, with an average of about $499 \mathrm{~mm}$. Precipitation is at its most scarce in March and October and the most abundant in July. Relative humidity averages $74 \%$, ranging from $62 \%$ in May to $-88 \%$ in December (http:/ /news.kr.ua).

The Padinska Skela site is under the influence of a temperate continental climate with pronounced seasons. The average annual air temperature is $10.9^{\circ} \mathrm{C}$, with 
the maximum coming in July $\left(37.1-42.3^{\circ} \mathrm{C}\right)$ and the minimum in January (-30.7$21.0^{\circ} \mathrm{C}$ ). The average July and January temperatures are $21.0^{\circ} \mathrm{C}$ and $-0.4^{\circ} \mathrm{C}$, respectively. The average amount of growing season precipitation is $364 \mathrm{~mm}$, while the average for the whole year is $615 \mathrm{~mm}$. June is the most rainy month, accounting for $12-13 \%$ of the total annual precipitation sum on the average. February and October have the least precipitation. Snow cover appears typically in the colder part of the year, from November to March, with January being the month the largest number of days with snow cover (http://hidmet.gov.rs).

\section{Data collection}

The study investigated the following seed quality parameters: germinability, 1,000-seed weight, the percentage of husk, protein content, and seed yield per hectare.

Seed germination was tested under laboratory conditions in the Laboratory for Seed Testing of the Institute of Field and Vegetable Crops in Novi Sad. The testing of seed germination was carried out in four replicates of 100 seeds using the standard laboratory test (ISTA, 2004). Wet sterilized sand was used as the germination medium. This parameter is determined after seed processing is completed in order to avoid the possible effects of seed dormancy.

1,000-seed weight was estimated from the weight of four samples of 100 seeds taken at random in each sample. The results were rounded to the nearest $0.01 \mathrm{~g}$.

The husk content (\%) of seed was calculated after manually dehulling $5.0 \mathrm{~g}$ of seed.

The protein content (\%) was measured by the Kjeldahl method (VAP-50-Gerhardt).

Seed yield was determined after the harvest and the measurements were adjusted to $9 \% \mathrm{MC}$.

\section{Statistical data analysis}

Data were analyzed using three-way ANOVA for a completely randomized design using statistical software STATISTICA 10. The significance of differences was determined by the least significant difference (LSD) test with significance thresholds at $1 \%$ and $5 \%($ Mead et al., 1996).

\section{RESULTS AND DISCUSSION}

Seed quality is a complex trait that depends on the genetic makeup of the hybrid, the planting date, and environmental conditions prevailing during the critical stages of plant development. The duration of the seed filling stage, temperatures, the distribution of precipitation, and nutritional conditions during the period following flowering are all known as significant factors affecting the yield and qual- 
ity of sunflower seed (Wardlaw and Moncur, 1995; Malešević, 2008). The same conclusion follows from the findings of Hrstkova et al. (2006), according to which the individual contribution of each trait varies depending on the specific response to environmental conditions.

Production conditions in sunflower seed production vary depending on both the production area and the production season. In years in which the conditions for sunflower growing are favorable high seed yields are obtained, but there are often years in which one or more stress periods will lead to the occurrence of yield losses (Škorić, 1988). Đukić et al. (2011) also report that yield levels, 1000-seed weight, and germinability are significantly determined by the amount and distribution of precipitation, temperature conditions during the growing season, and the time, duration and severity of the appearance of drought.

Table 1: F-values from ANOVA for influence of hybrid (H), production season (Ps), production region $(\mathrm{Pr})$ and interactions hybrid $\times$ production season (HPs), hybrid $\times$ production region ( $\mathrm{HPr}$ ), production season $\times$ roduction region $(\mathrm{PsPr})$ and hybrid $\times$ production season $\times$ production region (HPsPr) on sunflower seed quality parameters and yield

\begin{tabular}{|c|c|c|c|c|c|c|c|}
\hline & $\mathrm{H}$ & Ps & $\mathrm{Pr}$ & HPs & $\mathrm{HPr}$ & PsPr & HPsPr \\
\hline G & $<0.001^{\star \star}$ & $0.839^{\mathrm{ns}}$ & $0.383^{\text {ns }}$ & $0.636^{\text {ns }}$ & $0.636^{\text {ns }}$ & $0.164^{\mathrm{ns}}$ & $0.004^{\star \star}$ \\
\hline TKW & $<0.001^{\star *}$ & $0.008^{\star *}$ & $<0.001^{\star *}$ & $0.595^{\mathrm{ns}}$ & $<0.001^{\star *}$ & $<0.001^{* *}$ & $0.057^{\mathrm{ns}}$ \\
\hline$\% \mathrm{H}$ & $<0.001^{\star *}$ & $<0.001^{\star *}$ & $<0.001^{\star *}$ & $<0.001^{\star *}$ & $<0.001^{\star *}$ & $0.453^{\text {ns }}$ & $0.154^{\mathrm{ns}}$ \\
\hline$\%$ PR & $<0.001^{\star *}$ & $<0.001^{* *}$ & $<0.001^{* *}$ & $<0.001^{* *}$ & $<0.001^{* *}$ & $<0.001^{* *}$ & $0.216^{\mathrm{ns}}$ \\
\hline Y & $<0.001^{* *}$ & $0.855^{\mathrm{ns}}$ & $0.897^{\mathrm{ns}}$ & $0.054^{\mathrm{ns}}$ & $0.456^{\mathrm{ns}}$ & $0.753^{\mathrm{ns}}$ & $0.984^{\mathrm{ns}}$ \\
\hline
\end{tabular}

${ }^{* *}$ Significant at $1 \%$ level of probability and ${ }^{\text {ns }}$ not significant.

Table 1 shows the F-test probabilities of the variance analysis of the parameters studied, based on which it can be concluded that there was a highly significant effect of the hybrid (genotype) on all the investigated parameters ( $\mathrm{Fpr}=<0.001$ ). The production season and area had a highly significant influence on all the parameters except for germinability and yield, in the case of which there was no significance. These findings are only partially in agreement with those of Flagella et al. (2002), who reported that both genotype and year had a significant effect on yield components. Looking at the double interactions, it can be concluded that all the interactions had a highly significant effect only in the case of seed protein content, whereas in the case of germinability and yield none of the interactions had any significant effect. Looking at the triple interactions, it can be seen that the factors under study exhibited a highly significant influence on germinability.

\section{Seed germination}

Seed quality is determined by a large number of parameters and it cannot be said with certainty which one of them is the most important one. It is very important that sunflower seed quality be maintained at a high level in different production conditions. Knowing the interrelationships among all those different parameters is 
therefore of great importance not only from the point of view of selection but from the standpoint of production as well.

Table 2: Influence of production season and production region on seed germination in sunflower hybrids $(\%)$

\begin{tabular}{|c|c|c|c|c|c|c|c|}
\hline \multirow{2}{*}{\multicolumn{2}{|c|}{ Hybrid }} & \multirow{2}{*}{ Ps } & \multicolumn{2}{|c|}{$\mathrm{Pr}$} & \multirow{2}{*}{\multicolumn{2}{|c|}{$\begin{array}{c}\text { Average } \\
(\mathrm{H} \Delta \mathrm{Ps})\end{array}$}} & \multirow{2}{*}{$\begin{array}{c}\text { Average } \\
(\mathrm{H})\end{array}$} \\
\hline & & & Serbia & Ukraine & & & \\
\hline \multirow{2}{*}{\multicolumn{2}{|c|}{ NS-H-111 }} & 2007 & 92.25 & 89.25 & & & \multirow{2}{*}{90.62} \\
\hline & & 2008 & 87.75 & 93.25 & \multicolumn{2}{|c|}{90.50} & \\
\hline \multicolumn{2}{|c|}{ Average $(\mathrm{H} \Delta \mathrm{Pr})$} & & 90.00 & 91.25 & & & \multirow{3}{*}{94.56} \\
\hline \multirow{2}{*}{\multicolumn{2}{|c|}{ RIMI }} & 2007 & 93.25 & 95.25 & & & \\
\hline & & 2008 & 95.50 & 94.25 & & & \\
\hline \multicolumn{2}{|c|}{ Average $(\mathrm{H} \Delta \mathrm{Pr})$} & & 94.38 & 94.75 & \multicolumn{2}{|c|}{ Average (Ps) } & \multirow{3}{*}{92.59} \\
\hline \multirow{2}{*}{\multicolumn{2}{|c|}{ Average (Ps $\Delta \mathrm{Pr})$}} & 2007 & 92.75 & 92.25 & & & \\
\hline & & 2008 & 91.62 & 93.75 & & & \\
\hline \multicolumn{2}{|c|}{ Average $(\mathrm{Pr})$} & & 92.19 & 93.00 & & & \\
\hline & $\mathrm{H}$ & Ps & $\mathrm{Pr}$ & $\mathrm{H} \times \mathrm{Ps}$ & $\mathrm{H} \times \mathrm{Pr}$ & $\mathrm{Ps} \times \mathrm{Pr}$ & $\mathrm{H} \times \mathrm{Ps} \times \mathrm{Pr}$ \\
\hline $\mathrm{LSD}_{0,05}$ & 1.87 & 1.87 & 1.87 & 2.67 & 2.67 & 2.67 & 3.77 \\
\hline $\mathrm{LSD}_{0,01}$ & 2.55 & 2.55 & 2.55 & 3.61 & 3.61 & 3.61 & 5.11 \\
\hline
\end{tabular}

According to Crnobarac and Dušanić (1996) and Schoeman (2003), there are significant differences among hybrids, locations, and years of study when it comes to seed quality. In the present study germinability ranged from $87.75 \%$ in the hybrid NS-H-111 produced in Serbia in 2008 to $95.50 \%$ in the hybrid Rimi produced in Ukraine that same year (Table 2), as a result of which the $\mathrm{H} \times \operatorname{Ps} \times \operatorname{Pr}$ interaction was highly significant. The same finding was obtained by Pacheco et al. (2005), who reported that sunflower seed is greatly influenced by environmental factors, which most often results in high variability, both among different years in a single location and among different locations in a single year as well as among different locations and years. The germinability values in our study resulted in there being highly significant differences among the average values in the hybrids (3.94\%). The same results were obtained by Vega et al. (2001) and Rondanini et al. (2007), according to which germinability is a trait characteristic of each individual genotype. Looking at the production season and area as the factors, no significant difference were manifested.

\section{1,000-seed weight}

Thousand-seed weight is regarded as one of the most important factors when it comes to seed quality. It has been generally accepted that seeds used for planting should have as large 1000-seed weight as possible, because such seeds have larger amounts of storage substances and more developed embryos and also because plants they produce develop and grow faster, which is of great importance in areas where there is a great likelihood that unfavorable climatic factors may occur. 
According to Škorić (1988), it is necessary to have good knowledge of 1000-seed weight, because this trait has direct effect on the planting method and seeding rate and also indirectly influences the quality of the seeds to be produced as well seed yield per unit area.

Table 3: Influence of production season and production region on 1,000-seed weight in sunflower hybrids (g)

\begin{tabular}{|c|c|c|c|c|c|c|c|}
\hline \multirow{2}{*}{\multicolumn{2}{|c|}{ Hybrid }} & \multirow{2}{*}{ Ps } & \multicolumn{2}{|c|}{$\mathrm{Pr}$} & \multirow{2}{*}{\multicolumn{2}{|c|}{$\begin{array}{c}\text { Average } \\
(\mathrm{H} \Delta \mathrm{Ps})\end{array}$}} & \multirow{2}{*}{$\begin{array}{c}\text { Average } \\
(\mathrm{H})\end{array}$} \\
\hline & & & Serbia & Ukraine & & & \\
\hline \multirow{2}{*}{\multicolumn{2}{|c|}{ NS-H-111 }} & 2007 & 60.86 & 57.03 & & & \multirow{2}{*}{59.31} \\
\hline & & 2008 & 70.10 & 49.25 & \multicolumn{2}{|c|}{59.68} & \\
\hline \multicolumn{2}{|c|}{ Average $(\mathrm{H} \Delta \mathrm{Pr})$} & & 65.48 & 53.14 & & & \\
\hline \multirow{2}{*}{\multicolumn{2}{|c|}{ RIMI }} & 2007 & 51.99 & 54.24 & & & \multirow{2}{*}{53.64} \\
\hline & & 2008 & 60.33 & 48.02 & & & \\
\hline \multicolumn{2}{|c|}{ Average $(\mathrm{H} \Delta \mathrm{Pr})$} & & 56.16 & 51.13 & \multicolumn{2}{|c|}{ Average (Ps) } & \multirow{3}{*}{56.48} \\
\hline \multirow{2}{*}{\multicolumn{2}{|c|}{ Average (Ps $\triangle \mathrm{Pr})$}} & 2007 & 56.43 & 55.63 & & & \\
\hline & & 2008 & 65.21 & 48.64 & \multicolumn{2}{|c|}{56.92} & \\
\hline \multicolumn{2}{|c|}{ Average (Pr) } & & 60.82 & 52.13 & & & \\
\hline & $\mathrm{H}$ & Ps & $\mathrm{Pr}$ & $\mathrm{H} \times \mathrm{Ps}$ & $\mathrm{H} \times \mathrm{Pr}$ & $\mathrm{Ps} \times \mathrm{Pr}$ & $\mathrm{H} \times \mathrm{Ps} \times \mathrm{Pr}$ \\
\hline $\mathrm{LSD}_{0,05}$ & 0.66 & 0.66 & 0.66 & 0.90 & 0.90 & 0.90 & 1.27 \\
\hline $\mathrm{LSD}_{0,01}$ & 0.86 & 0.86 & 0.86 & 1.22 & 1.22 & 1.22 & 1.72 \\
\hline
\end{tabular}

Results shown in Table 3 indicate that, besides the hybrid, it was the production area that had the largest influence on 1000-seed weight. The variation of 1000seed weight is characteristic of different hybrids in a single location as well as of a single hybrid in different locations (Marinković, 1992). In the present study we found highly significant differences among the production areas themselves $(8.69 \%)$ as well as in all the interactions in which the production area was one of the factors. The same finding was reported by Villegas et al. (2010), who found a highly significant effect of the location $\times$ genotype interaction on 1000-seed weight. Dušanić (1998), on the other hand, argues that 1000-seed weight depends first and foremost on the year of study, the hybrid, and the seeding rate.

\section{Husk content}

The components of oil percentage of sunflower seeds are the husk content and oil content in the kernel (Dedio, 1982). Selection of sunflower varieties with high oil contents has led to a reduction in seed size and percentage hull, with kernels adhering very tightly to the hull (Denis et al., 1994). A hull percentage that is too low may lead to problems arising during machine-harvesting and seed processing in sunflower.

The husk content in our study ranged from $20.35 \%$ in NS-H-111 to $31.40 \%$ in Rimi (Table 4). On the average, the studied factors individually resulted in highly significant differences $(6.69 \%$ for the hybrids, $1.97 \%$ for the production season, and $1.67 \%$ for the production area). With the interactions too there were highly signifi- 
cant differences in all the treatments, the only exception being the hybrid NS-H-111, in the case of which the differences between the hybrid $\times$ production season interaction and the hybrid $\times$ production area one turned out not to be statistically significant.

Table 4: Influence of production season and production region on husk content in sunflower hybrids (\%)

\begin{tabular}{|c|c|c|c|c|c|c|c|}
\hline \multirow{2}{*}{\multicolumn{2}{|c|}{ Hybrid }} & \multirow{2}{*}{ Ps } & \multicolumn{2}{|c|}{$\mathrm{Pr}$} & \multirow{2}{*}{\multicolumn{2}{|c|}{$\begin{array}{c}\text { Average } \\
(\mathrm{H} \Delta \mathrm{Ps})\end{array}$}} & \multirow{2}{*}{$\begin{array}{c}\text { Average } \\
(\mathrm{H})\end{array}$} \\
\hline & & & Serbia & Ukraine & & & \\
\hline \multirow{2}{*}{\multicolumn{2}{|c|}{ NS-H-111 }} & 2007 & 20.75 & 20.73 & & & \multirow{2}{*}{20.63} \\
\hline & & 2008 & 20.70 & 20.35 & \multicolumn{2}{|c|}{20.53} & \\
\hline \multicolumn{2}{|c|}{ Average $(\mathrm{H} \Delta \mathrm{Pr})$} & & 20.73 & 20.54 & & & \\
\hline \multirow{2}{*}{\multicolumn{2}{|c|}{ RIMI }} & 2007 & 23.75 & 26.75 & & & \multirow{2}{*}{27.32} \\
\hline & & 2008 & 27.38 & 31.40 & & & \\
\hline \multicolumn{2}{|c|}{ Average $(\mathrm{H} \Delta \mathrm{Pr})$} & & 25.56 & 29.08 & \multicolumn{2}{|c|}{ Average (Ps) } & \multirow{3}{*}{23.98} \\
\hline \multirow{2}{*}{\multicolumn{2}{|c|}{ Average $(\mathrm{Ps} \Delta \mathrm{Pr})$}} & 2007 & 22.25 & 23.74 & & & \\
\hline & & 2008 & 24.04 & 25.88 & \multicolumn{2}{|c|}{24.96} & \\
\hline \multicolumn{2}{|c|}{ Average $(\mathrm{Pr})$} & & 23.14 & 24.81 & & & \\
\hline & $\mathrm{H}$ & Ps & $\mathrm{Pr}$ & $\mathrm{H} \times \mathrm{Ps}$ & $\mathrm{H} \times \mathrm{Pr}$ & $\mathrm{Ps} \times \mathrm{Pr}$ & $\mathrm{H} \times \mathrm{Ps} \times \mathrm{Pr}$ \\
\hline $\mathrm{LSD}_{0.05}$ & 0.47 & 0.47 & 0.47 & 0.67 & 0.67 & 0.67 & 0.95 \\
\hline $\mathrm{LSD}_{0.01}$ & 0.64 & 0.64 & 0.64 & 0.91 & 0.91 & 0.91 & 1.28 \\
\hline
\end{tabular}

\section{Seed protein content}

Although sunflower as a crop is grown primarily for its high seed oil content, it is a significant source of protein as well. According to Denis et al. (1994), the average seed protein content of sunflower varies from 30 to $33 \%$ for the whole kernel but may be anywhere in the $25-45 \%$ range. The same author indicates that this character is influenced by the genotype as well as by environmental factors. Dušanić (1998) too has reported that seed protein content in sunflower is significantly influenced by the choice of hybrid, location, and year of production.

According to our results shown in Table 5, all of the studied factors had a highly significant influence on seed protein content. This significance manifested itself both through individual influences and through interactions themselves. The sole exception were the results obtained for NS-H-111, in the case of which the difference recorded for the hybrid $\times$ production season interaction was not significant $(0.01 \%)$, with the values being nearly identical.

Many authors have studied the effects of different factors on seed protein content in sunflower. According to Triboi et al. (2000), for instance, environmental conditions have a considerable influence on protein content and composition. The same authors also regard the quantitative effect as being the most important. Hristov et al. (2010) studied the effects of the genotype, environment, and their interaction on seed quality in wheat and found high statistical significance for almost all the traits. The exception was the protein content, in the case of which high signifi- 
cance was recorded only for the interaction. The same authors also reported that the year, location, and their interaction had a significant influence on the protein content, whereas in the case of the genotype $\times$ year location interaction no significance was observed.

Table 5: Influence of production season (Ps) and production region ( $\mathrm{Pr}$ ) on seed protein content in sunflower hybrids (\%)

\begin{tabular}{|c|c|c|c|c|c|c|c|}
\hline \multirow{2}{*}{\multicolumn{2}{|c|}{ Hybrid }} & \multirow{2}{*}{ Ps } & \multicolumn{2}{|c|}{$\mathrm{Pr}$} & \multirow{2}{*}{\multicolumn{2}{|c|}{$\begin{array}{c}\text { Average } \\
\text { (H } \Delta \mathrm{Ps})\end{array}$}} & \multirow{2}{*}{$\begin{array}{l}\text { Average } \\
(\mathrm{H})\end{array}$} \\
\hline & & & Serbia & Ukraine & & & \\
\hline \multirow{2}{*}{\multicolumn{2}{|c|}{ NS-H-111 }} & 2007 & 20.91 & 17.85 & \multirow{2}{*}{\multicolumn{2}{|c|}{$\begin{array}{l}19.38 \\
19.39\end{array}$}} & 19.39 \\
\hline & & 2008 & 20.20 & 18.58 & & & \\
\hline \multicolumn{2}{|c|}{ Average $(\mathrm{H} \Delta \mathrm{Pr})$} & & 20.56 & 18.21 & & & \\
\hline \multirow{2}{*}{\multicolumn{2}{|c|}{ RIMI }} & 2007 & 24.21 & 22.70 & \multicolumn{2}{|c|}{23.45} & 22.35 \\
\hline & & 2008 & 21.61 & 20.90 & \multicolumn{2}{|c|}{21.25} & \\
\hline \multicolumn{2}{|c|}{ Average $(\mathrm{H} \Delta \mathrm{Pr})$} & & 22.91 & 21.80 & \multicolumn{2}{|c|}{ Average (Ps) } & \\
\hline \multirow{2}{*}{\multicolumn{2}{|c|}{ Average $(\mathrm{Ps} \Delta \mathrm{Pr})$}} & 2007 & 22.56 & 20.27 & \multicolumn{2}{|c|}{21.42} & \\
\hline & & 2008 & 20.91 & 19.74 & \multicolumn{2}{|c|}{20.32} & 20.87 \\
\hline \multicolumn{2}{|c|}{ Average $(\mathrm{Pr})$} & & 21.73 & 20.01 & & & \\
\hline & $\mathrm{H}$ & Ps & $\mathrm{Pr}$ & $\mathrm{H} \times \mathrm{Ps}$ & $\mathrm{H} \times \mathrm{Pr}$ & $\mathrm{Ps} \times \mathrm{Pr}$ & $\mathrm{H} \times \mathrm{Ps} \times \mathrm{Pr}$ \\
\hline $\mathrm{LSD}_{0,05}$ & 0.26 & 0.26 & 0.26 & 0.36 & 0.36 & 0.36 & 0.52 \\
\hline $\mathrm{LSD}_{0,01}$ & 0.35 & 0.35 & 0.35 & 0.49 & 0.49 & 0.49 & 0.70 \\
\hline
\end{tabular}

\section{Seed yield}

One of the main focuses of sunflower breeding is the development of hybrids with a high genetic potential for seed yield. Jocić (2003) considers seed yield a complex trait with a polygenic basis that is highly influenced by the environment. According to Gunasekera et al. (2006), seed yield is a quantitative trait, the expression of which is the result of the genotype, environment and the interaction between the genotype and the environment.

The results of the present study indicate that on average the seed yield of the studied hybrids was affected the most by the genotype (Table 6). The difference that was created $(833.0 \mathrm{~kg})$ was highly statistically significant. On the average, looking at the production season and area as factors, differences were observed with regard to seed yield, but those were not statistically significant. The same conclusion was reported by Villegas et al. (2010), whose findings showed that despite the diversity of environmental conditions, the main differences in yield were due to genotypes. According to Marjanović-Jeromela et al. (2011), however, seed yield per plant is highly influenced by environmental factors, which indicates the adaptability of specific genotypes to specific seasons. 
Table 6: Influence of production season (Ps) and production region (Pr) on seed yield in sunflower hybrids (kg/ha)

\begin{tabular}{|c|c|c|c|c|c|c|c|}
\hline \multirow{2}{*}{\multicolumn{2}{|c|}{ Hybrid }} & \multirow{2}{*}{ Ps } & \multicolumn{2}{|c|}{$\mathrm{Pr}$} & \multirow{2}{*}{\multicolumn{2}{|c|}{$\begin{array}{c}\text { Average } \\
(\mathrm{H} \Delta \mathrm{Ps})\end{array}$}} & \multirow{2}{*}{$\begin{array}{c}\text { Average } \\
\text { (H) }\end{array}$} \\
\hline & & & Serbia & Ukraine & & & \\
\hline \multirow{2}{*}{\multicolumn{2}{|c|}{ NS-H-111 }} & 2007 & 1550.0 & 1412.0 & \multirow{2}{*}{\multicolumn{2}{|c|}{$\begin{array}{l}1481.0 \\
1274.0\end{array}$}} & \multirow{2}{*}{1378.0} \\
\hline & & 2008 & 1305.0 & 1243.0 & & & \\
\hline \multicolumn{2}{|c|}{ Average $(\mathrm{H} \Delta \mathrm{Pr})$} & & 1428.0 & 1328.0 & \multicolumn{2}{|c|}{100} & \\
\hline \multirow{2}{*}{\multicolumn{2}{|c|}{ RIMI }} & 2007 & 402.0 & 439.0 & \multirow{2}{*}{\multicolumn{2}{|c|}{$\begin{array}{l}420.0 \\
669.0\end{array}$}} & 5450 \\
\hline & & 2008 & 617.0 & 721.0 & & & 340.0 \\
\hline \multicolumn{2}{|c|}{ Average $(\mathrm{H} \Delta \mathrm{Pr})$} & & 510.0 & 580.0 & \multicolumn{2}{|c|}{ Average (Ps) } & \\
\hline \multirow{2}{*}{\multicolumn{2}{|c|}{ Average $(\mathrm{Ps} \Delta \mathrm{Pr})$}} & 2007 & 976.0 & 926.0 & \multicolumn{2}{|c|}{951.0} & 9610 \\
\hline & & 2008 & 961.0 & 982.0 & \multicolumn{2}{|c|}{972.0} & 001.0 \\
\hline \multicolumn{2}{|c|}{ Average (Pr) } & & 968.0 & 954.0 & & & \\
\hline & $\mathrm{H}$ & Ps & $\mathrm{Pr}$ & $\mathrm{H} \times \mathrm{Ps}$ & $\mathrm{H} \times \mathrm{Pr}$ & $\mathrm{Ps} \times \mathrm{Pr}$ & $\mathrm{H} \times \mathrm{Ps} \times \mathrm{Pr}$ \\
\hline $\mathrm{LSD}_{0,05}$ & 232.2 & 232.2 & 232.2 & 328.4 & 328.4 & 328.4 & 464.4 \\
\hline $\mathrm{LSD}_{0,01}$ & 314.7 & 314.7 & 314.7 & 445.0 & 445.0 & 445.0 & 629.3 \\
\hline
\end{tabular}

\section{CONCLUSION}

Seed quality parameters as well as yield itself depend primarily on the conditions during the growing season, which is why special attention needs to be paid to choosing the right production area. In our study of the effects of production season and area on seed quality parameters and seed yields of two sunflower hybrids, there was a highly significant influence of the hybrid/genotype on all the parameters studied. Production season and area had a highly significant effect on all the studied parameters except for seed germinability and yield, in the case of which no significance was recorded. A highly significant effect of all the interactions was manifested only in the case of seed protein content, while looking at the triple interaction it was observed that the studied factors had a highly significant effect on seed germinability.

\section{ACKNOWLEDGEMENTS}

This work was supported by the Ministry of Education, Science and Technological Development, Republic of Serbia, Project TR 31025. 


\section{REFERENCES}

Adugna, W. and Labushange, M.T., 2002. Genotype-environment interactions and phenotypic stability analysis of linseed in Ethiopia. Plant Breeding 121: 66-71.

Aguirrezabal, L.A.N., Lavaud, Y., Dosio, G.A.A., Izquierdo, N.A., Andrade, F.H. and Gonzalez, L.M., 2003. Intercepted solar radiation during seed filling determines sunflower weight per seed and oil concentration. Crop Sci. 43: 152-161.

Chloupek, O., Hrstkova, P. and Jurecka, D., 2003. Tolerance of barley seed germination to coldand drought-stress expressed as seed vigour. Plant Breeding 122: 199-203.

Crnobarac, J. and Dušanić, N., 1996. Possibility of increasing and stabilization yields of sunflower. Period. Sci. Res. Field Veg. Crop. 25: 13-26 (in Serbian).

Dedio, W., 1982. Variability in hull content, kernel oil content, and whole seed oil content of sunflower hybrids and parental lines. Can. J. Plant Sci. 62: 51-54.

Denčić, S., Mladenov, N. and Kobiljski, B., 2011. Effects of genotype and environment on breadmaking quality in wheat. Int. J. Plant Prod. 5(1): 71-82.

Denis, L., Dominguez, J., Baldini, M. and Vear, F., 1994. Genetical studies of hullability in comparison with other sunflower seed characteristics. Euphytica 79: 29-38.

Dušanić, N., 1998. Effect of stand density on growth dynamics, yield, and some microclimatic factors in sunflower hybrids. PhD Thesis, Faculty of Agriculture, University of Novi Sad, Serbia (in Serbian).

Đukić, V., Balešević-Tubić, S., Đorđević, V., Tatić, M., Dozet, G., Jaćimović, G. and Petrović, K., 2011 . Yield and quality of soybean seeds as affected by growing conditions. Ratar. Povrt. 48(1): 137-142 (in Serbian).

Flagella, Z., Rotunno, T., Tarantino, E., Di Caterina, R. and De Caro, A., 2002. Changes in seed yield and oil fatty acid composition of high oleic sunflower (Helianthus annuus L.) hybrids in relation to the sowing date and the water regime. Eur. J. Agron. 17: 221-230.

Gunasekera, C.P., Martin, L.D., Siddique, K.H.M. and Walton, G.H., 2006. Genotype by environment interactions of Indian mustard (Brassica juncea L.) and canola (B. napus L.) in Mediterranean-type environments. II. Oil and protein concentration in seed. Eur. J. Agron. 25: 13-21.

Hristov, N., Mladenov, N., Djurić, V., Kondić-Špika, A., Marjanović-Jeromela, A. and Simić, D., 2010. Genotype by environment interactions in wheat quality breeding programs in southeast Europe. Euphytica 174: 315-324.

Hrstkova, P., Chloupek, O. and Bebarova, J., 2006. Estimation of barley seed vigour with respect to variety and provenance effects. Czech J. Genet. Plant. 42(2): 44-49.

ISTA, 2004. International rules for seed testing. International Seed Testing Association, Switzerland.

Jocić, S., 2003. Inheritance of yield components in sunflower (Helianthus annuus L.). PhD Thesis, Faculty of Agriculture, University of Novi Sad, Serbia (in Serbian).

Malešević, M., 2008. Mineral nutrition of small grains in integrated crop management system. Period. Sci. Res. Field Veg. Crop. 45(1): 179-193 (in Serbian).

Marinković, R., 1992. Path-coefficient analysis of some yield components of sunflower (Helianthus annuus L.). Euphytica 60: 201-205.

Marjanović-Jeromela, A., Nagl, N., Gvozdanović-Varga, J., Hristov, N., Kondić-Špika, A., Vasić, M. and Marinković, R., 2011. Genotype by environment interaction for seed yield per plant in rapeseed using AMMI model. Pesqui. Agropecu. Bras. 46(2): 174-181.

Mead, R., Curnow, R.N. and Hasted, A.M., 1996. Statistical methods in agriculture and experimental biology. Chapman and Hall, London, UK.

Miklič, V., Balalić, I., Jocić, S., Marinković, R., Cvejić, S., Hladni, N. and Miladinović, D., 2010. Stability estimation for seed and oil yield of NS sunflower hybrids in small-plot trials and recommendations for 2010 sowing season. Ratar. Povrt. 47(1): 131-146 (in Serbian).

Miklič, V., Dušanić, N. and Jocić, S., 2011. Sunflower seed production. In: Milošević, M. and Kobiljski, B. (Eds.) Seed production. Institute of Field and Vegetable Crops, Novi Sad, Vol 2:196-264 (in Serbian).

Moghaddam, M.J. and Pourdad, S.S., 2011. Genotype $\times$ environment interactions and simultaneous selection for high oil yield and stability in rainfed warm areas rapeseed (Brassica napus L.) from Iran. Euphytica 180: 321-335.

Mrdja, J., Crnobarac, J., Dušanić, N., Jocić, S. and Miklič, V., 2011. Germination energy as a parameter of seed quality in different sunflower genotypes. Genetika-Belgrade 43(3): 427436. 
Nasayao, L.Z. and Saladaga, F.A., 1988. Genotype $\times$ environment interaction for yield in sweet potato (Ipomoea batatas L.). Philipp. J. Crop Sci. 13(2): 99-104.

Nyachiro, J.M., Clarke, F.R., Depauw, R.M., Knox, R.E. and Armstrong, K.C., 2002. Temperature effects on seed germination and expression of seed dormancy in wheat. Euphytica 126: 123-127.

Pacheco, R.M., Duarte, J.B., Vencovsky, R., Pinheiro, J.B. and Oliviera, A.B., 2005. Use of supplementary genotypes in AMMI analysis. Theor. Appl. Genet. 110: 812-818.

Radić, V., Vujaković, M., Marjanović-Jeromela, A., Mrdja, J., Miklič, V., Dušanić, N. and Balalić, I., 2009. Interdependence of sunflower seed quality parameters. Helia 32(50): 157-164.

Rahman, M.A., Chikushi, J., Yoshida, S. and Karim, A.J.M.S., 2009. Growth and yield components of wheat genotypes exposed to high temperature stress under control environment. Bangladesh J. Agril. Res. 34(4): 361-372.

Rondanini, D.P., Savin, R. and Hall, A.J., 2007. Estimation of physiological maturity in sunflower as a function of fruit water concentration. Eur. J. Agron. 26: 295-309.

Sidlauskas, G. and Bernotas, S., 2003. Some factors affecting seed yield of spring rapeseed (Brassica napus L.). Agronomy Research 1(2): 229-243.

Schoeman, L.J., 2003. Genotype $\times$ environment interaction in sunflower (Helianthus annuus) in South Africa. PhD Thesis. University of the Free State, Bloemfontein, South Africa.

Škorić, D., 1988. Sunflower breeding. Uljarstvo 25(1): 1-90 (in Serbian).

Škorić, D., Jocić, S., Lečić, N. and Sakač, Z., 2008. Genetic possibilities for altering sunflower oil quality to obtain novel oils. Can. J. Physiol. Pharmacol. 86 (4): 215-221.

Triboi, E., Abad, A., Michelena, A., Lloveras, J., Ollier, J.L. and Daniel, C., 2000. Environmental effects on the quality of two wheat genotypes: 1. quantitative and qualitative variation of storage proteins. Eur. J. Agron. 13: 47-64.

Vega, C.R.C., Andrade, F.H. and Sadras, V.O., 2001. Reproductive partitioning and seed efficiency in soybean, sunflower and maize. Field Crop. Res. 72: 163-175.

Villegas, D., Casadesus, J., Atienza, S.G., Martos, V., Maalouf, F., Karam, F., Aranjuelo, I. and Nogues, S., 2010. Tritordeum, wheat and triticale yield components under multi-local mediterranean drought conditions. Field Crop. Res. 116: 68-74.

Vujaković, M., Radić, V., Miklič, V., Jovičić, D., Balešević-Tubić, S., Mrđa, J. and Škorić, D., 2012. Seed dormancy of hybrids and parent lines of sunflower (Helianthus annuus L.). Helia 35(56): 111-118.

Wardlaw, I.F. and Moncur, L., 1995. The response of wheat to high temperature following anthesis. I. The rate and duration of kernel filling. Aust. J. Plant Physiol. 22(3): 391-397. 